Handbuch Minnesang 



\section{Handbuch Minnesang}

Herausgegeben von

Beate Kellner, Susanne Reichlin und Alexander Rudolph

\section{DE GRUYTER}


ISBN 978-3-11-035181-1

e-ISBN (PDF) 978-3-11-035185-9

e-ISBN (EPUB) 978-3-11-038762-9

Library of Congress Control Number: 2020949513

\section{Bibliografische Information der Deutschen Nationalbibliothek}

Die Deutsche Nationalbibliothek verzeichnet diese Publikation in der Deutschen Nationalbibliografie; detaillierte bibliografische Daten sind im Internet über http://dnb.dnb.de abrufbar.

(C) 2021 Walter de Gruyter GmbH, Berlin/Boston Umschlagabbildung: Universitätsbibliothek Heidelberg, Große Heidelberger Liederhandschrift (Cod. Pal. germ. 848), fol. 71v.

Datenkonvertierung/Satz: Dörlemann Satz, Lemförde

Druck und Bindung: CPI books GmbH, Leck

www.degruyter.com 